\title{
Edukasi Tindakan Pencegahan Penyakit Infeksi bagi Petugas Kebersihan Terkait Pandemik Covid-19
}

\author{
Mulyanti Roberto Muliantino, Yuanita Ananda, Boby Febri Krisdiyanto, dan \\ Leni Merdawati \\ Fakultas Keperawatan, Universitas Andalas, Kampus Limau Manis, Padang, 25163. Indonesia \\ E-mail: mulyantiola@yahoo.com
}

Keywords:

Covid-19,

education,

infection disease, preventive care

Kata Kunci:

Covid-19, edukasi, pencehagan, penyakit infeksi

\begin{abstract}
Cleaning workers was one of high risk workers in Covid-19 infection who exposed to garbage from individuals, households and business waste every day. During Covid-19 pandemic there was increased disposal of infectious waste such as masks and gloves from households without sorting process which increasing risk of infection for cleaning workers. Preventive effort of cleaning workers was needed as vigilance in daily activities. Therefore, an education was carried out about prevention of infectious disease related Covid-19 pandemic to improving knowledge and understanding of cleaning workers as preventive measure. Education program was carried out to 50 cleaning workers in Environmental Department of Padang on 29-30 June 2020. Modules, videos, and demonstrations procedures of hand washing, mask and glove using were used in these educations. Education program consist of basic concepts and preventive measures against infectious disease related Covid-19 pandemic. The results showed there was increased knowledge of cleaning workers about preventive way against infectious disease related Covid-19 pandemic after participating in education program.
\end{abstract}

\footnotetext{
ABSTRAK

Pada masa pandemik Covid-19 petugas kebersihan memiliki resiko tinggi terjangkit infeksi. Setiap hari petugas kebersihan terpapar dengan sampah sebagai limbah perorangan, rumah tangga dan badan usaha. Peningkatan pembuangan limbah infeksius seperti masker dan sarung tangan dari rumah tangga tanpa adanya proses pemilahan semakin meningkatkan resiko terhadap petugas kebersihan. Upaya pecegahan dalam bentuk kewaspadaan petugas kebersihan sangat penting dalam melakukan pekerjaan. Oleh karena itu, untuk meningkatkan pengetahuan dan pemahaman petugas kebersihan dilakukan edukasi tentang tindakan pencegahan penyakit infeksi terkait pandemik Covid-19 sebagai upaya preventif. Edukasi dilakukan kepada 50 orang petugas kebersihan di bawah Dinas Lingkungan Hidup kota Padang pada tanggal 29-30 Juni 2020. Media edukasi menggunakan modul, video, pemaparan materi power point dan demonstrasi cuci tangan, penggunaan masker dan sarung tangan. Program edukasi mencakup konsep dasar penyakit infeksi dan tindakan pencegahan terhadap penyakit infeksi terkait pandemik Covid19. Hasil evaluasi menunjukkan terdapat peningkatan pengetahuan petugas kebersihan tentang tindakan pencegahan terhadap penyakit infeksi terkait pandemik Covid-19 setelah mengikuti kegiatan edukasi.
} 


\section{PENDAHULUAN}

Seiring merebaknya infeksi virus SARS-CoV-2 (coronavirus) di Wuhan pada Desember 2019 dan pada 31 Januari 2020 pandemik ini menyebar dengan cepat ke berbagai negara di dunia. (Adhikari et al, 2020). Berdasarkan data World Health Organization (WHO) tanggal 20 Juli 2020 terdapat 14.348.858 kasus konfirmasi positif dan kematian mencapai 603.691 orang yang tersebar di 216 negara. Pandemik Covid-19 di Indonesia telah ditetapkan sebagai Status Keadaan Tertentu Darurat Bencana Wabah Penyakit Akibat Virus Corona. Jumlah kasus positif mencapai 88.214 kasus dan 4.239 meninggal hingga pertengahan Juli 2020 (Kementrian Kesehatan Republik Indonesia, 2020). Berdasarkan data pantauan Covid-19 Provinsi Sumatera Barat terdapat 828 kasus terkonfirmasi positif Covid-19 per tanggal 20 Juli 2020.

Dalam kondisi pandemik ini petugas kebersihan merupakan kelompok beresiko tinggi untuk terinfeksi coronavirus. Petugas kebersihan adalah pekerja yang tidak dapat melaksanakan tugas di rumah (tempat tinggal) sehingga dalam kondisi pandemik tetap bekerja seperti biasa. Petugas kebersihan di kota Padang berada di bawah Dinas Lingkungan Hidup Kota Padang pada Bidang Pengelolaan Sampah dan Kebersihan. Petugas kebersihan memiliki tugas melakukan pembersihan sampah, pengelolaan, pemilahan, pengumpulan dan pengangkutan sampah skala daerah atau kawasan (Peraturan Walikota Padang Nomor 76 Tahun 2016). Berdasarkan pernyataan Kepala Dinas Lingkungan Hidup Kota Padang bahwa sekitar 700 petugas kebersihan bekerja setiap hari, mereka bekerja normal dan tidak ada pengurangan jam kerja. Terkait status KLB dan penyebaran Covid-19, petugas diingatkan untuk bekerja secara disiplin, menjaga kebersihan diri, menggunakan sarung tangan dan mencuci tangan menggunakan sabun.

Petugas kebersihan dapat terjangkit Covid-19 akibat limbah infeksius yang dihasilkan rumah tangga. Limbah infeksius dari rumah tangga pada masa pandemik Covid-19 mengalami peningkatan seperti pemakaian masker dan penggunaan sarung tangan yang dibuang tanpa ada pengelolaan atau pemilahan limbah (Amalia, V., Hadisantoso, E.P., Wahyuni, I.R., \& Supriatna, A.M, 2020). Petugas kebersihan yang sehari-hari terpapar dengan sampah tidak hanya beresiko tinggi terinfeksi Covid-19 namun juga terancam infeksi akibat pembusukan sampah. Sampah merupakan limbah dapat dalam bentuk padat, setengah padat, limbah cair yang berasal dari kegiatan orang pribadi atau usaha yang terdiri dari bahan organik, non organik, logam dan bukan logam, yang dapat terbakar, termasuk buangan biologis atau kotoran manusia/lumpur tinja. Proses pembusukan sampah oleh mikroorganisme menghasilkan gas yang menimbulkan bau busuk seperti amonia hydrogen, sulfide dan metylmercaptan yang dapat menyebabkan penyakit sesak nafas dan penyakit mata. Infeksi saluran cerna (diare, kolera dan typus) juga dapat terjadi akibat terkontaminasi bakteri dan kuman dari sampah. Insiden penyakit kulit dan infeksi cacing Ascaris lumbricoides, Trichuris trichiura, Hookworm dan Enterobius vermicularis juga sering pada petugas kebersihan dan pengangkut sampah. Studi yang dilakukan Nur Islami (2014) dari 59 orang petugas pengangkut sampah menemukan terdapat 31 orang diantaranya mengalami infeksi cacing. Kurangnya penggunaan alat pelindung diri (APD) dan belum optimalnya tindakan personal hygiene sebagai tindakan pencegahan infeksi menjadi faktor utama yang menyebabkan insiden.

Petugas kebersihan perlu meningkatkan kewaspadaan dan melakukan tindakan pencegahan penyakit infeksi dengan menjaga personal hygiene, penggunaan alat pelindung diri dan menerapkan kewaspadaan umum. Hasil observasi di lapangan petugas kebersihan terpapar sampah dan limbah dari masyarakat umum dengan alat pelindung diri seadanya, masih banyak petugas kebersihan yang tidak memakai APD seperti masker, sarung tangan, rompi badan, kaca mata pelindung dan sepatu kerja. Hal ini mengindikasikan masih rendahnya kewaspadaan 
petugas kebersihan terhadap penularan penyakit infeksi tidak terkecuali terinfeksi virus SARSCoV-2.

Tindakan pencegahan penyakit infeksi (preventive care in community) menjadi kunci utama untuk menekan penyebaran penyakit infeksi termasuk Covid-19. Berdasarkan evidence yang ada tindakan preventif yang dapat dilakukan yaitu meningkatkan personal hygiene, penggunaan alat pelindung diri (APD) yang benar dan menerapkan kewaspadaan umum yang meliputi menjaga kontak fisik atau menjaga jarak sosial (social/physical distancing) minimal 1 meter dari individu yang mengalami gangguan pernafasan, menutup mulut jika batuk ataupun bersin (Direktorat Jenderal Pencegahan Dan Pengendalian Penyakit Kementerian Kesehatan Republik Indonesia, 2020; WHO, 2020). Untuk meningkatkan pengetahuan petugas kebersihan perlu dilakukan edukasi tentang tindakan pencegahan penyakit infeksi terkait pandemik Covid-19. Program edukasi ini dilakukan pada petugas kebersihan kota Padang yang berada di bawah Dinas Lingkungan Hidup. Kegiatan ini bertujuan untuk meningkatkan pengetahuan dan pemahaman petugas kebersihan tentang tindakan pencegahan penyakit infeksi terkait pandemik Covid-19 sehingga dapat diterapkan dalam beraktivitas sehari-hari.

\section{METODE}

Pelaksanaan kegiatan edukasi dilakukan selama 2 hari pada tanggal 29 - 30 Juni 2020 kepada 50 orang petugas kebersihan di bawah Dinas Lingkungan Hidup Kota Padang. Kegiatan edukasi dilaksanakan di Aula Dinas Lingkungan Hidup Kota Padang dengan tetap memperhatikan standar protokol kesehatan. Sebelum masuk aula untuk mengikuti edukasi seluruh peserta melakukan cuci tangan, melakukan hand hygiene menggunakan handsanitizer, menggunakan masker dan tempat duduk diatur dengan jarak 0,5 - 1 meter antar peserta.

Metode pelaksanaan kegiatan edukasi yang telah dilakukan mencakup:

1. Pengurusan izin kepada Kepala Dinas Lingkungan Hidup untuk melakukan edukasi tentang tindakan pencegahan penyakit infeksi kepada petugas kebersihan.

2. Sosialisasi dengan Jajaran Dinas Lingkungan Hidup Kota Padang dan menyusun teknis pelaksanaan kegiatan bersama tim dan Jajaran Dinas Lingkungan Hidup Kota Padang.

3. Menyiapkan media edukasi berupa modul "Edukasi Tindakan Pencegahan Penyakit Infeksi Bagi Petugas Kebersihan Terkait Pandemik Covid-19" yang mencakup konsep ringkas penyakit infeksi yang dapat menyerang petugas kebersihan dan tindakan pencegahannya. Modul dikemas dalam bentuk mini booklet, dilengkapi gambar-gambar yang menarik dan bahasa yang mudah dipahami. Selain itu tim edukasi juga menyiapkan materi dalam bentuk slide power poin dan video demonstrasi cuci tangan untuk dipaparkan dalam kegiatan edukasi.

4. Survei lapangan untuk pengecekan kembali tempat pelaksanaan kegiatan edukasi.

5. Persiapan tempat dan perlengkapan. Tim edukasi bersama petugas Dinas Lingkungan Hidup Kota Padang menyiapkan aula untuk kegiatan edukasi, melakukan pengaturan tempat duduk peserta dengan jarak 0,5 - 1 meter antar peserta, memasang spanduk kegiatan edukasi, menyiapkan peralatan dalam kegiatan edukasi antara lain laptop, infokus serta screen. Tim edukasi juga menyiapkan 2 masker dan 1 sarung tangan bagi masing-masing petugas kebersihan untuk diajarkan cara penggunaan alat pelindung diri dan dapat digunakan dalam bekerja.

6. Sebelum registrasi peserta kegiatan edukasi melakukan cuci tangan dengan air dan sabun, setelah itu melakukan hand hygiene dengan handsanitizer dan menggunakan masker. 
Kemudian melakukan registrasi dan mengambil edukasi kit yang terdiri dari modul edukasi, lembar pre tes, pulpen, masker dan sarung tangan.

7. Tim edukasi melakukan pretest untuk mengetahui pemahaman awal petugas kebersihan terkait tindakan pencegahan penyakit infeksi.

8. Tim edukasi melakukan penyuluhan kepada petugas kebersihan dengan memaparkan materi menggunakan power point, memutar video cuci tangan, melakukan demonstrasi cuci tangan bersama petugas kebersihan dan cara penggunaan alat pelindung diri.

9. Tim edukasi melakukan evaluasi pemahaman petugas kebersihan mengenai materi yang diberikan melalui postest.

10. Data hasil pretest dan postest yang dilakukan pada petugas kebersihan dilakukan analisis menggunakan analisis univariat dan data univariat disajikan dalam bentuk tabel distribusi frekuensi. Analisis bivariat menggunakan uji T-dependen untuk menilai perbedaan pengetahuan petugas kebersihan tentang tindakan pencegahan penyakit infeksi terkait pandemik Covid-19 sebelum dan setelah mengikuti program edukasi dengan tingkat kepercayaan $95 \%(p<0,05)$.

\section{HASIL DAN PEMBAHASAN}

Kegiatan edukasi dilaksanakan di aula Dinas Lingkungan Hidup Kota Padang pada tanggal 29 - 30 Juni 2020 kepada 50 orang petugas kebersihan yang berada di bawah Dinas Lingkungan Hidup Kota Padang. Tim dosen yang melakukan edukasi adalah Ns. Mulyanti Roberto Muliantino, M.Kep, Ns. Yuanita Anand, M.Kep, dan Ns. Boby Febri Krisdianto, M.Kep. Tim edukasi juga dibantu dua orang mahasiswa yaitu Mery Christiany dan Asra Dewita. Edukasi tindakan pencegahan penyakit infeksi ini dilakukan melalui metode penyuluhan dengan pemaparan materi, memutar video dan demonstrasi yang dilakukan pada 25 orang petugas kebersihan pada hari pertama dan 25 orang petugas kebersihan pada hari kedua. Kegiatan ini tetap memperhatikan standar protokol kesehatan, dimana peserta wajib mencuci tangan dan melakukan hand hygiene sebelum registrasi, menggunakan masker dan tempat duduk diatur dengan jarak 0,5 - 1 meter antar peserta. Adapun karakteristik petugas kebersihan yang mengikuti program edukasi terdapat pada Tabel 1.

Tabel 1. Karakteristik petugas kebersihan yang mengikuti program edukasi.

\begin{tabular}{lcc}
\hline \multicolumn{1}{c}{ Karakteristik } & Frekuensi & Persentase (\%) \\
\hline Usia & & \\
20-29 tahun & 18 & 36 \\
30-39 tahun & 17 & 34 \\
$40-49$ tahun & 14 & 28 \\
50 tahun ke atas & 1 & 2 \\
Jenis Kelamin & & \\
Laki-laki & 30 & 60 \\
Perempuan & 20 & 40 \\
Pendidikan & & 2 \\
SD & 1 & 10 \\
SMP & 5 & 88 \\
SMA & 44 & \\
Keluhan Kesehatan & & 4 \\
Mudah Lelah & 2 & \\
\hline
\end{tabular}




\begin{tabular}{lcc}
\hline Sakit Tenggorokan & 1 & 2 \\
Batuk & 3 & 6 \\
Tidak Ada Keluhan & 44 & 88 \\
\hline
\end{tabular}

Dari Tabel 1 diatas dapat dilihat sebagian besar petugas kebersihan yang mengikuti program edukasi berusia dewasa muda, dan mayoritas adalah laki-laki (60\%). Sebagian besar tingkat pendidikan petugas kebersihan yang mengikuti program edukasi ada Sekolah Menengah Atas (SMA). Empat puluh empat orang dari 50 petugas kebersihan tidak memiliki keluhan kesehatan.

Identifikasi pengetahuan awal petugas kebersihan tentang tindakan pencegahan penyakit infeksi terkait pandemik Covid-19 dilakukan melalui pre tes. Setelah mengikuti program edukasi, dilakukan post test untuk mengevaluasi pemahaman petugas kebersihan terhadap materi yang diberikan. Hasil analisis pengetahuan petugas kebersihan disajikan pada Tabel 2 .

Tabel 2. Perbedaan pengetahuan petugas kebersihan tentang tindakan pencegahan penyakit infeksi sebelum dan setelah mengikuti edukasi.

\begin{tabular}{|c|c|c|c|c|c|}
\hline $\begin{array}{l}\text { Pengetahuan Petugas Kebersihan } \\
\text { Tentang Tindakan Pencegahan } \\
\text { Penyakit Infeksi }\end{array}$ & $\mathbf{n}$ & Mean & SD & SE & $p$ \\
\hline Pre tes & & 7,92 & 0,829 & 0,117 & \\
\hline Post tes & 50 & 9,60 & 0,756 & 0,107 & $<0,001$ \\
\hline
\end{tabular}

Tabel 2 di atas menunjukkan rerata pengetahuan petugas kebersihan sebelum dilakukan program edukasi yaitu 7,92 dan rerata pengetahuan petugas kebersihan setelah dilakukan program edukasi menjadi 9,60. Hasil analisis lebih lanjut menggunakan Uji T-dependen menunjukkan terdapat perbedaan signifikan antara pengetahuan petugas kebersihan tentang tindakan pencegahan penyakit infeksi terkait pandemik Covid-19 sebelum dilakukan program edukasi dan setelah dilakukan edukasi $(p=<0,001)$.

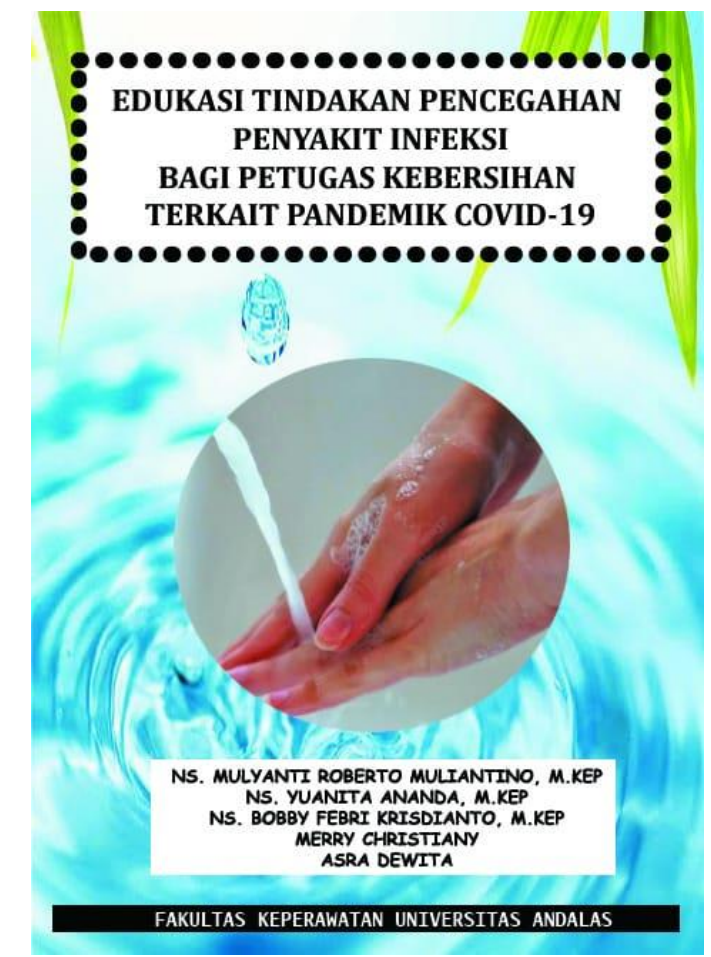

Gambar 1. Modul edukasi yang digunakan 


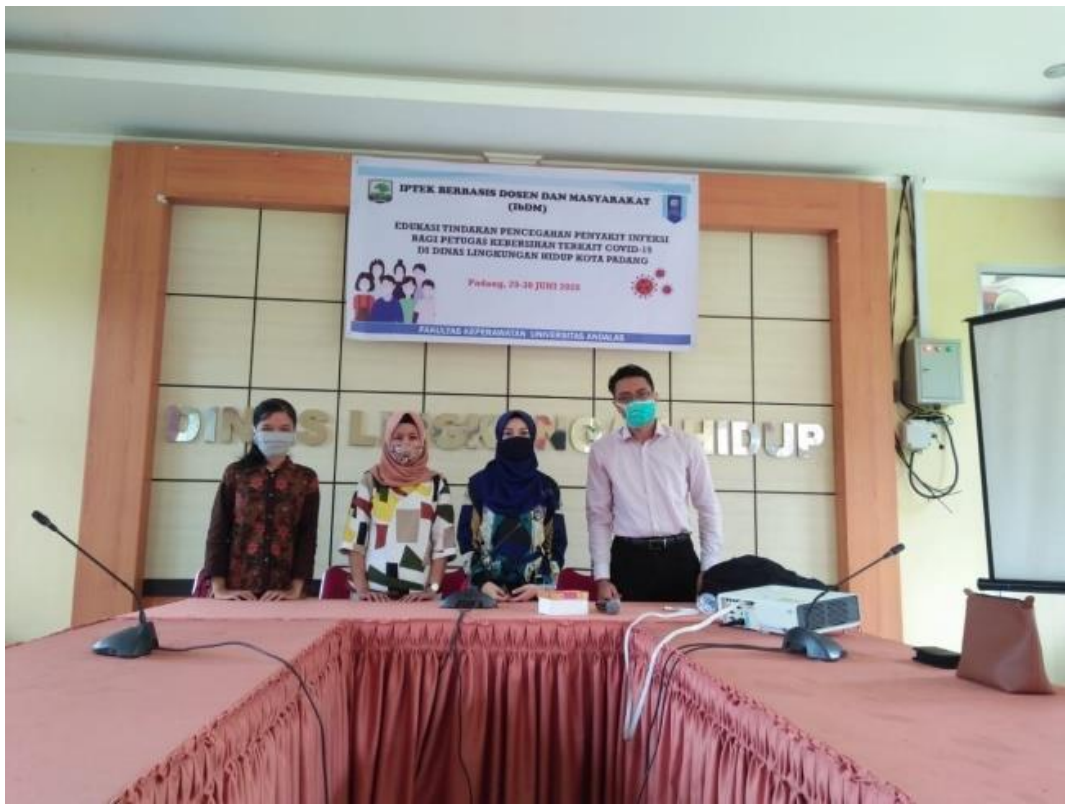

Gambar 2. Tim yang melakukan edukasi

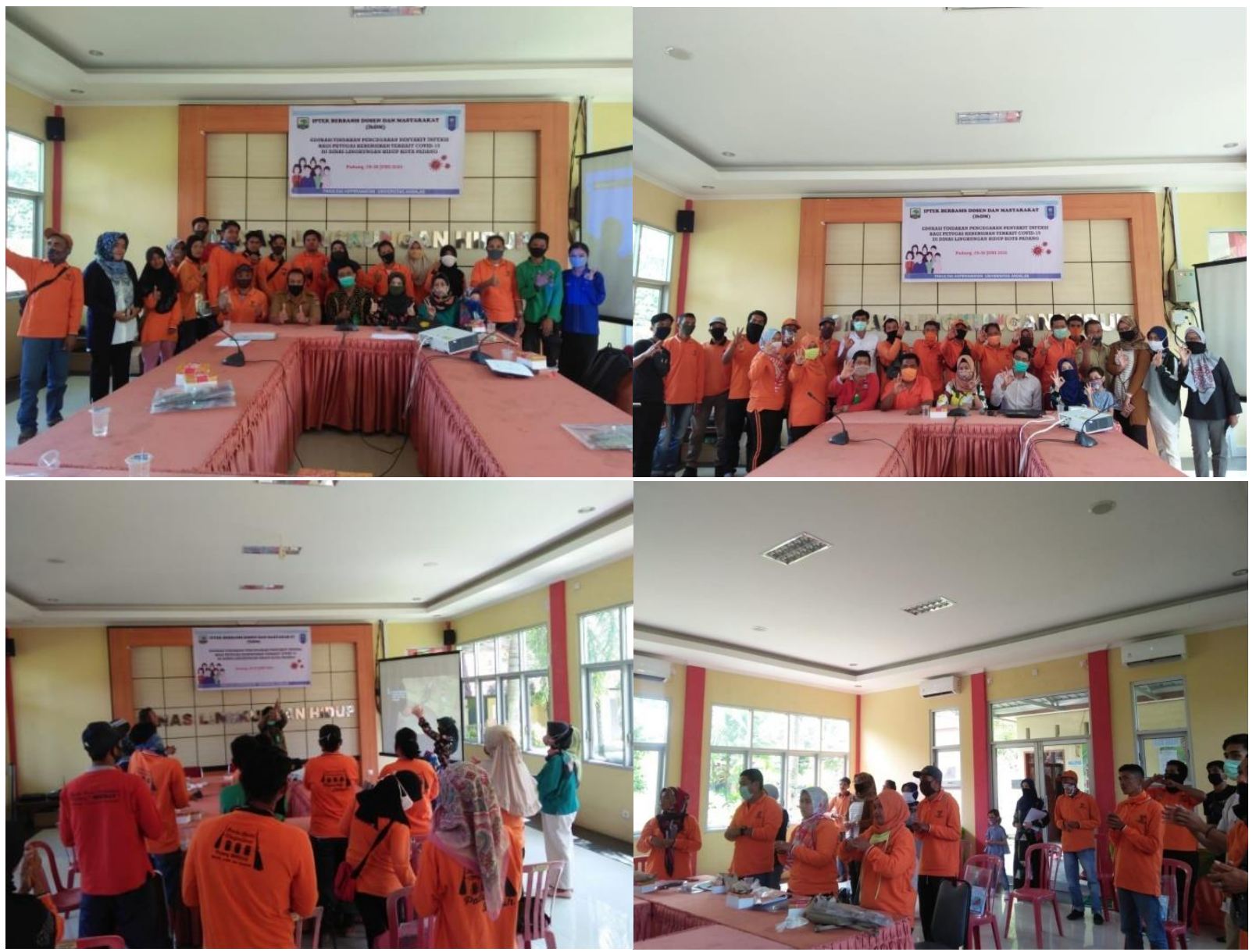

Gambar 3. Kegiatan edukasi pada petugas kebersihan 
Edukasi tentang tindakan pencegahan penyakit infeksi terkait pandemik Covid-19 kepada petugas kebersihan merupakan upaya untuk memutus rantai penularan penyakit. Metode edukasi menggunakan modul, pemutaran video dan demonstrasi sangat efektif untuk meningkatkan pengetahuan petugas kebersihan. Menurut Sulaeman \& Supriadi (2020) selain pengetahuan tentang Covid-19 masyarakat juga penting dibekali dengan kunci penting untuk terhindar dari transmisi virus Covid-19 yaitu pengetahuan tentang kesehatan dan pola hidup bersih dan sehat. Pemberian materi ini dapat membantu masyarakat terhindar dari penyakit infeksi termasuk infeksi Covid-19. Penyuluhan kesehatan dapat meningkatkan kesadaran dan pengetahuan masyarakat terhadap pentingnya menjaga lingkungan dan diri agar tetap sehat dan terbebas dari penyakit infeksi.

Penggunaan media edukasi yang menarik bagi petugas kebersihan dapat meningkatkan animo dan mempermudah peserta program edukasi memahami materi yang diberikan. Perubahan dalam tatanan masyarakat yang disebabkan sebagian besar oleh proses transmisi informasi, dengan orang-orang yang selalu terhubung dan terus menerus mendapat informasi tentang apa yang terjadi dalam kehidupan masyarakat. Dalam penyebaran informasi terkait Covid-19, media dan teknologi dapat digunakan sebagai bentuk pendidikan bagi masyarakat. Media dapat menjadi lembaga sosial sebagai sumber informasi bagi masyarakat untuk meningkatkan pengetahuan masyarakat (Sampurno, Kusumandyoko \& Islam, 2020).

\section{KESIMPULAN}

Program edukasi tentang tindakan pencegahan penyakit infeksi terkait pandemik Covid-19 pada petugas kebersihan sangat efektif dilakukan. Hal ini dapat dilihat dari hasil analisis peningkatan pengetahuan petugas kebersihan tentang tindakan pencegahan penyakit infeksi terkait pandemik Covid-19 setelah mengikuti program edukasi. Upaya preventif ini dapat dilakukan secara berkesinambungan melalui kerjasama lintas sektoral, sehingga dapat menurunkan angka kejadian infeksi pada petugas kebersihan dan memutus rantai penularan Covid-19.

\section{UCAPAN TERIMA KASIH}

Penulis menyampaikan ucapan terima kasih kepada Unit Penelitian dan Pengabdian Kepada Masyarakat Fakultas Keperawatan Universitas Andalas, sebagai penyandang dana kegiatan program edukasi ini dan kepada Dinas Lingkungan Hidup Kota Padang selaku mitra dalam kegiatan edukasi.

\section{DAFTAR PUSTAKA}

Adhikari et al. (2020). Epidemiology, causes, clinical manifestation and diagnosis, prevention and control of coronavirus disease (COVID-19) during the early outbreak period: a scoping review. Infectious Diseases of Poverty 9:29. doi.org/10.1186/s40249-020-00646-x

Amalia, V., Hadisantoso,E.P., Wahyuni, I.R., \& Supriatna, A.M. 2020. Penanganan Limbah Infeksius Rumah Tangga Pada Masa Wabah COVID-19. UIN Sunan Gunung Jati: Bandung. 
Biro Humas Provinsi Sumatera Barat. 2020. Data Pantauan Covid-19 Provinsi Sumatera Barat. https://corona.sumbarprov.go.id/

Kementrian Kesehatan Republik Indonesia. 2020. Situasi COVID-19. https://kemkes.go.id/

Nur Islami, R., Sulastrianah., Asfiyah Udu, S Wa Ode. (2014). Perbedaan Kejadian Infeksi Cacing Antara Petugas Pengangkut Sampah Yang Menggunakan Alat Pelindung Diri Dengan Petugas Pengangkut Sampah Yang Tidak Menggunakan Alat Pelindung Diri. Medula Volume 2 No 1 (Oktober).

https://www.antaranews.com/berita/1388182/petugas-kebersihan-di-padang-kerja-normalsaat-status-klb-covid-19 Diakses 30 Maret 2020

Pedoman Kesiapsiagaan Menghadapi Infeksi Novel Coronavirus (2019-nCov). 2020. Direktorat Jenderal Pencegahan Dan Pengendalian Penyakit Kementerian Kesehatan Republik Indonesia.

Peraturan Walikota Padang Nomor 76 Tahun 2016 Tentang Kedudukan, Susunan Organisasi, Tugas, Fungsi dan Tata Kerja Dinas Lingkungan Hidup.

World Health Organization (WHO). 2020. Rational use of personal protective equipment for coronavirus disease 2019 (COVID-19).

World Health Organization (WHO). 2020. Coronavirus Disease (COVID-19) Pandemic. https://www.who.int/emergencies/diseases/novel-coronavirus-

2019?gclid=CjwKCAjwgdX4BRB_EiwAg808HRWUNAlZYJKVWtxg4anCOXqlqt5X5j19yH0Zge GI3daVyqbnwmM29BoCUkkQAvD_BwE

Sulaeman \& Supriadi. 2020. Peningkatan Pengetahuan Masyarakat Desa Jelantik Dalam Menghadapi Pandemi Corona Virus Diseases-19 (Covid-19). Jurnal Hasil Pengabdian \& $\begin{array}{llllll}\text { Pemberdayaan } & \text { Kepada } & \text { Masyarakat. } & \text { Vol } & 1 & \text { No.1: }\end{array}$ http://ojs.ikipmataram.ac.id/index.php/jpu

Sampurno, M.B.T., Kusumandyoko, T.C., \& Islam, M.A. 2020. Budaya Media Sosial, Edukasi Masyarakat dan Pandemi COVID-19. SALAM; Jurnal Sosial \& Budaya Syar-i. Vol. 7 No. 6 (2020), pp. 529-542, DOI: 10.15408/sjsbs.v7i5.15210 